\title{
PELATIHAN PENGGUNAAN APLIKASI EDMODO BAGI GURU SMP DAN SMA SMART INDONESIA PEKANBARU
}

\author{
Raudhah Awal ${ }^{* 1}$, Sri Wahyuni ${ }^{2}$, Martala Sari ${ }^{3}$ \\ ${ }^{1,2,3}$ Universitas Lancang Kuning; Jl. Yos Sudarso KM 8 Rumbai, Telp. (0761) 53108 - 53236 \\ Program Studi Pendidikan Biologi, Fakultas Keguruan dan Ilmu Pendidikan \\ *E-mail: raudhahawal@gmail.com
}

\begin{abstract}
The use of ICT in the education sector has increased. The use of sophisticated electronic devices such as computers and mobile phones that can be connected to the internet has become the most popular among the public, especially educators and students. Teachers in SMP and SMA Smart Indonesia Pekanbaru have not used modern ICT tools in learning. Through Community Service activities, SMP and SMA Smart Indonesia Pekanbaru teachers were given training on the use of learning applications in modern ICT tools, Edmodo. The results of the Community Service activities that have been carried out are known to have increased the knowledge of SMP and SMA Smart Indonesia Pekanbaru teachers regarding the use of Edmodo applications. The average pretest score is 16 or $16 \%$ and the average posttest value is 100 or $100 \%$.
\end{abstract}

\section{Keywords - Edmodo, Learning Innovation, Modern ICT}

\begin{abstract}
Abstrak
Penggunaan TIK pada bidang pendidikan sudah semakin meningkat. Penggunaan alatalat elektronik canggih seperti komputer dan telepon genggam yang dapat terhubung dengan internet menjadi paling diminati oleh masyarakat, terkhusus pendidik maupun peserta didik. Guru di SMP dan SMA Smart Indonesia Pekanbaru belum menggunakan alat TIK modern dalam pembelajaran. Melalui kegiatan Pengabdian Kepada Masyarakat, guru SMP dan SMA Smart Indonesia Pekanbaru diberikan pelatihan tentang penggunaan aplikasi pembelajaran pada alat TIK modern, yaitu Edmodo. Hasil kegiatan Pengabdian Kepada Masyarakat yang telah dilakukan diketahui terjadi peningkatan pengetahuan guru SMP dan SMA Smart Indonesia Pekanbaru mengenai penggunaan aplikasi Edmodo. Rerata nilai pretest adalah 16 atau $16 \%$ dan rerata nilai posttest adalah 100 atau $100 \%$.
\end{abstract}

Kata kunci-Edmodo, Inovasi Pembelajaran, TIK Modern

\section{PENDAHULUAN}

$\mathrm{T}$ eknologi Informasi dan Komunikasi (TIK) sebagai bagian dari Ilmu Pengetahuan dan Teknologi (IPTEK) secara umum adalah semua teknologi yang berhubungan dengan pengambilan, pengumpulan (akuisisi), pengolahan, penyimpanan, penyebaran dan penyajian informasi (Kementerian Negara Riset dan Teknologi RI dalam Budiana et al., 2015). TIK merupakan suatu program untuk alat bantu manipulasi dan menyampaikan informasi. TIK adalah payung besar terminologi yang mencakup seluruh peralatan teknis untuk memproses dan menyampaikan informasi. Jika ditinjau dari asal sebuah kata, kata teknologi berasal dari bahasa Yunani, technologia atau techne yang mempunyai arti keahlian dan logia yang berarti pengetahuan (Darimi, 2017).

Memasuki abad ke 21 ini, perkembangan TIK sudah semakin meningkat di segala bidang. Peran TIK tidak terbantahkan dapat mempermudah aktivitas manusia. Mulai dari aktivitas seharihari, pekerjaan, hingga pendidikan pun tidak terlepas dari penggunaan TIK. Pengguna TIK pun berasal dari berbagai kalangan usia, dari anak-anak hingga orang tua.

Penggunaan TIK pada bidang pendidikan tidak terbatas pada penggunaan alat-alat elektronik yang canggih (sophisticated) atau modern, seperti pemanfaatan komputer dan internet, 
melainkan juga mencakup alat-alat yang konvensional, seperti: bahan tercetak, kaset audio, Overhead Transparancy (OHT)/ Overhead Projector (OHP), bingkai suara (sound slides), radio, dan televisi (Siahaan, 2010). Namun, penggunaan alat-alat elektronik canggih seperti komputer dan telepon genggam yang dapat terhubung dengan internet menjadi paling diminati oleh masyarakat, terkhusus pendidik maupun peserta didik.

Kecenderungan penggunaan alat TIK modern dibandingkan TIK konvensional disebabkan karena banyaknya kemudahan yang didapat penggunanya. Sebagai contoh dalam bidang pendidikan, pendidik maupun peserta didik dapat mencari berbagai informasi terkait bahan pembelajaran melalui sebuah komputer maupun telepon genggam. Banyak buku dari penulis dalam dan luar negeri yang memiliki harga yang cukup mahal, kini tersedia dalam bentuk $e$-book yang bisa diunduh oleh siapapun. Selain itu, tersedia juga berbagai aplikasi pembelajaran yang dapat digunakan pendidik untuk memudahkan proses pembelajaran.

Peran guru dan siswa dalam proses pembelajaran jelas berubah-ubah karena adanya pengaruh teknologi. Guru dan buku teks tidak lagi menjadi sumber belajar satu-satunya yang utama dan tidak ada bandingannya. Guru telah berubah peran menjadi seorang fasilitator pemerolehan informasi. Bahkan dengan beberapa tombol keyboard, para pelajar dapat menjelajahi berbagai informasi dunia, memperoleh akses dari perpustakaan dan sekumpulan informasi penting lainnya untuk mendapatkan pengetahuan dan keterampilan barunya. Fenomena yang terjadi di kalangan masyarakat yang memandang bahwa tugas guru hanya seorang pengajar (pentransfer ilmu) di lingkungan pendidikan perlu untuk dirubah. Karena sejatinya seorang guru bukan hanya sebagai pengajar untuk mencerdaskan pola pemikiran anak didik yang dari tidak tahu menjadi tahu (Fahyuni, 2017).

Salah satu aplikasi yang dapat digunakan pada proses pembelajaran adalah aplikasi Edmodo. Menurut Okmayura et al. (2018), edmodo adalah sebuah situs yang diperuntukkan bagi pendidik untuk membuat kelas virtual. Situs tersebut gratis dan gampang digunakannya selama seorang guru dan murid bisa terhubung dengan internet. Edmodo adalah sebuah jawaban bagi sebuah ruang kelas virtual yang nyaman dan aman, dikarenakan:

1. Siswa dapat melakukan interaksi dalam pantauan gurunya (bebas cyber crime).

2. Guru dapat mengunci siswa, dengan demikian ia hanya bisa membaca dan tidak bisa berkomentar pada seisi 'kelas' namun tetap ia bisa berkomunikasi langsung dengan gurunya.

3. Tidak ada orang luar yang bisa masuk dan melihat kelas virtual yang dibuat oleh seorang guru tanpa mendapat kode khusus dari guru yang bersangkutan.

4. Guru dapat memulai pertanyaan, menaruh foto atau video, menaruh presentasi bahan ajar, yang kesemuanya bebas untuk diunduh oleh siswa dan dikomentari.

5. Murid bisa kembali kapan saja untuk mengulang materi yang diberikan gurunya, bahkan Pekerjaan Rumah (PR) bisa diberikan melalui Edmodo.

6. Murid juga bisa mengumpulkan PR nya lewat Edmodo, tinggal mengunggah saja. Edmodo bisa dipadukan dengan situs lain seperti wall wisher, glogster dan lain sebagainya.

7. Guru bisa menaruh nilai dari pekerjaan siswa sebagai acuan bagi siswa.

Sekolah Menengah Pertama (SMP) dan Sekolah Menengah Atas (SMA) Smart Indonesia Pekanbaru adalah sekolah swasta yang ada di Kecamatan Rumbai Pesisir, Kota Pekanbaru. SMP Smart Indonesia Pekanbaru memiliki 6 orang guru dan SMA Smart Indonesia Pekanbaru memiliki 10 orang guru. Berdasarkan informasi yang diperoleh dari mahasiswa Program Pengalaman Lapangan (PPL) yang melakukan observasi kegiatan pembelajaran, diketahui bahwa guru di SMP dan SMA Smart Indonesia Pekanbaru belum menggunakan alat TIK modern dalam pembelajaran. Selain itu, melalui wawancara tim pengusul pengabdian dengan guru SMP dan SMA Smart Indonesia Pekanbaru diketahui bahwa guru memerlukan variasi dalam proses pembelajaran, salah satunya dengan penggunaan aplikasi Edmodo. Melalui penggunaan aplikasi Edmodo ini diharapkan dapat meningkatkan kompetensi guru dalam mengajar sehingga akan bermuara pada peningkatan minat dan hasil belajar siswa.

Solusi dari permasalahan mitra adalah sebagai berikut:

1. Guru SMP dan SMA Smart Indonesia Pekanbaru diberikan materi tentang berbagai variasi penggunaan aplikasi pembelajaran pada alat TIK modern. 
2. Guru SMP dan SMA Smart Indonesia Pekanbaru diberikan pelatihan penggunaan aplikasi Edmodo sebagai variasi dalam proses pembelajaran, sehingga diharapkan dapat meningkatkan kompetensi guru dalam mengajar dan akan bermuara pada peningkatan minat dan hasil belajar siswa.

\section{METODE}

Prosedur yang dilakukan dalam kegiatan pengabdian ini terbagi menjadi 2 sesi yang dilakukan selama 1 hari. Sesi pertama berupa seminar tentang berbagai variasi penggunaan aplikasi pembelajaran pada alat TIK modern, kemudian sesi kedua diisi dengan pelatihan penggunaan aplikasi Edmodo.

\subsection{Kegiatan Sesi 1}

Pada sesi ini, peserta diberikan pembekalan ilmu tentang berbagai variasi penggunaan aplikasi pembelajaran pada alat TIK modern. Sesi 1 ini terdiri dari: penyampaian materi, tanya jawab, dan diskusi. Materi disampaikan oleh Ibu Raudhah Awal, M.Pd. Kegiatan ini dimulai dari pukul 13.30 - 14.00 WIB.

\section{2. $\quad$ Kegiatan Sesi 2}

Pada sesi 2, peserta diberikan pelatihan berupa praktik penggunaan aplikasi Edmodo. Pelatihan ini dibimbing oleh Ibu Sri Wahyuni, M.Si. Kegiatan ini dimulai dari pukul 14.00 - 16.30 WIB.

Sebelum kegiatan sesi 1 dimulai dan setelah kegiatan sesi 2 selesai, peserta diberikan pretest dan posttest untuk mengevaluasi tingkat pemahaman peserta.

\section{HASIL DAN PEMBAHASAN}

Pengabdian Kepada Masyarakat yang berjudul "Pelatihan Penggunaan Aplikasi Edmodo Bagi Guru SMP dan SMA Smart Indonesia Pekanbaru" ini dilakukan pada hari Jum'at (11 Januari 2019) di ruang serba guna SMP Smart Indonesia Pekanbaru. Peserta pelatihan ini terdiri dari 6 orang guru SMP dan 6 orang guru SMA, sehingga total peserta pelatihan adalah 12 orang guru SMP dan SMA Smart Indonesia Pekanbaru. Narasumber dalam kegiatan ini adalah Raudhah Awal, M.Pd. dan Sri Wahyuni, M.Si. yang merupakan Tim Pengabdi.

Pelatihan dilaksanakan mulai pukul 13.30 WIB dan berakhir pada pukul 17.00 WIB. Pelatihan ini dibagi menjadi 2 sesi. Sesi 1 merupakan penyampaian materi mengenai berbagai variasi penggunaan aplikasi pembelajaran pada alat TIK modern. Sesi 1 ini terdiri dari: pretest, penyampaian materi, tanya jawab dan diskusi. Materi disampaikan oleh Raudhah Awal, M.Pd. Kegiatan ini dimulai dari pukul 13.30 - 14.00 WIB. Pada awal sesi ini disampaikan kata pembuka acara dari Ketua Tim Pengabdi serta pemberian motivasi mengenai manfaat nyata yang akan didapatkan oleh mitra melalui kegiatan ini. Kemudian diberikan lembar pretest kepada peserta pelatihan untuk mengukur pengetahuan awal peserta mengenai materi dan praktik Edmodo yang akan dilakukan. Selama sesi 1 ini berlangsung, peserta tampak antusias dalam mengikuti kegiatan. Hal ini dapat dilihat dari tanya jawab dan diskusi mengalir dengan lancar dari peserta kegiatan. Banyak pertanyaan yang diajukan seputar aplikasi pembelajaran yang berbasis IT. 


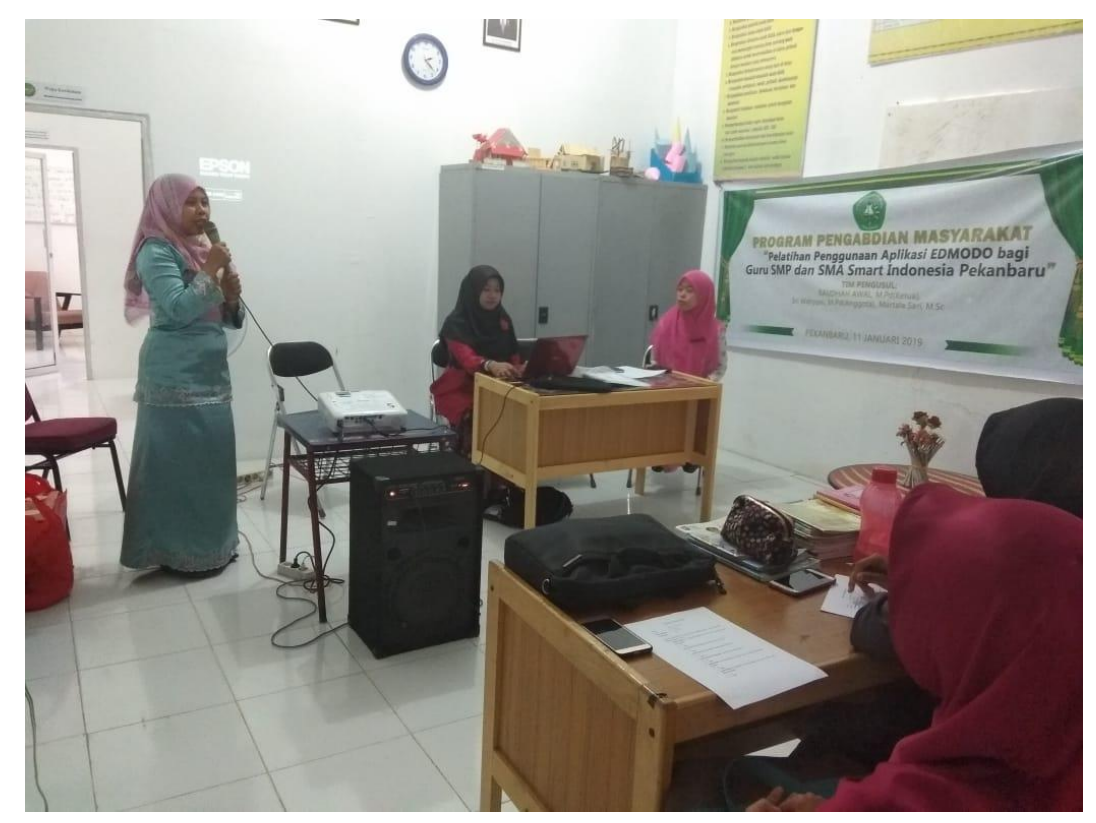

Gambar 1. Penyampaian Materi Pelatihan

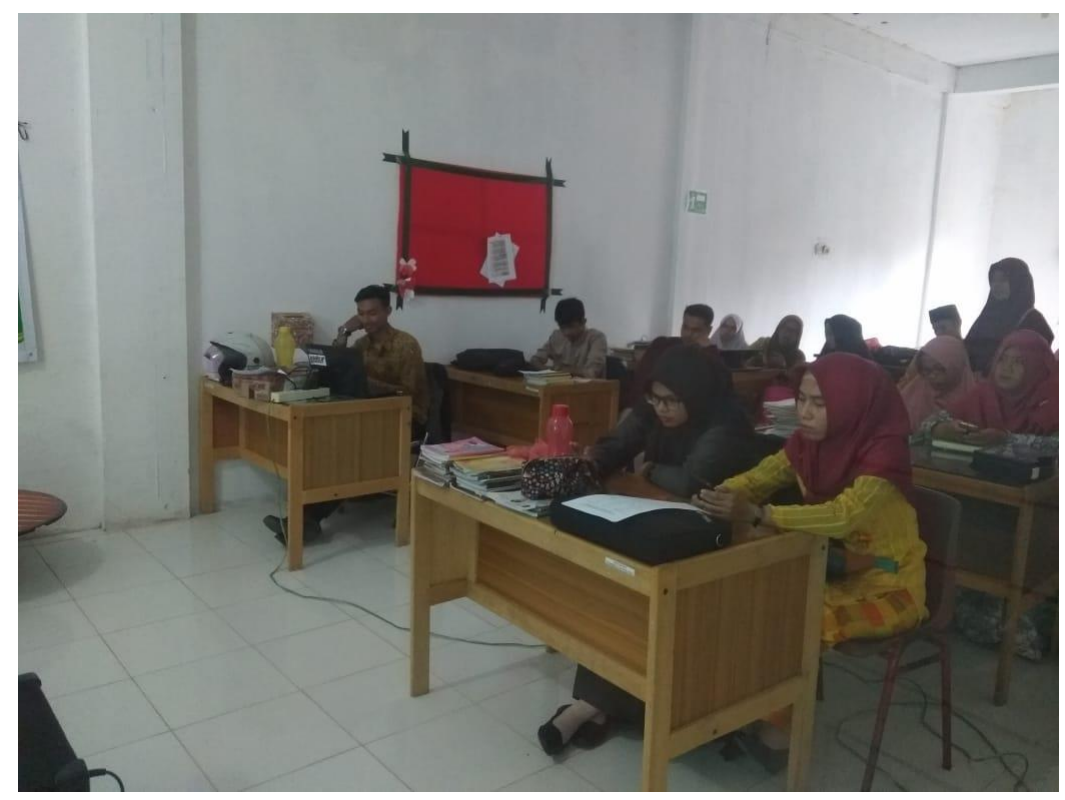

Gambar 2. Pengerjaan Pretest

Setelah kegiatan sesi 1 selesai, dilanjutkan dengan kegiatan sesi 2 yang merupakan pelatihan praktik penggunaan aplikasi Edmodo. Pelatihan ini dibimbing oleh Sri Wahyuni, M.Si. Kegiatan ini dimulai dari pukul 14.00 - 16.30 WIB. Pada sesi 2 ini peserta terlihat antusias dalam mengikuti praktik penggunaan aplikasi Edmodo. Banyak pertanyaan diajukan peserta terkait penggunaan aplikasi Edmodo di sela-sela praktik. Kegiatan praktik ini juga melibatkan peserta secara aktif yaitu dengan memberikan kesempatan kepada 2 orang perwakilan dari peserta untuk mencobakan langsung di depan peserta lainnya tentang cara menggunakan aplikasi Edmodo. Sementara itu, peserta lain mempraktikkannya melalui laptop atau handphone masing-masing. Pada praktik ini, dipelajari cara membuat akun Edmodo, cara membuat grup/ kelompok, cara mengunggah bahan ajar di library, cara membuat catatan/ note, cara membuat pengumuman/ alert, cara membuat penugasan/ assignment, dan cara membuat calendar Edmodo. Di akhir kegiatan, semua peserta sudah memiliki akun Edmodo masing-masing. Setelah kegiatan sesi 2 berakhir, 
peserta diberi lembar posttest untuk mengevaluasi tingkat pemahaman peserta mengenai materi maupun praktik yang telah didapatkan dan dilakukan.

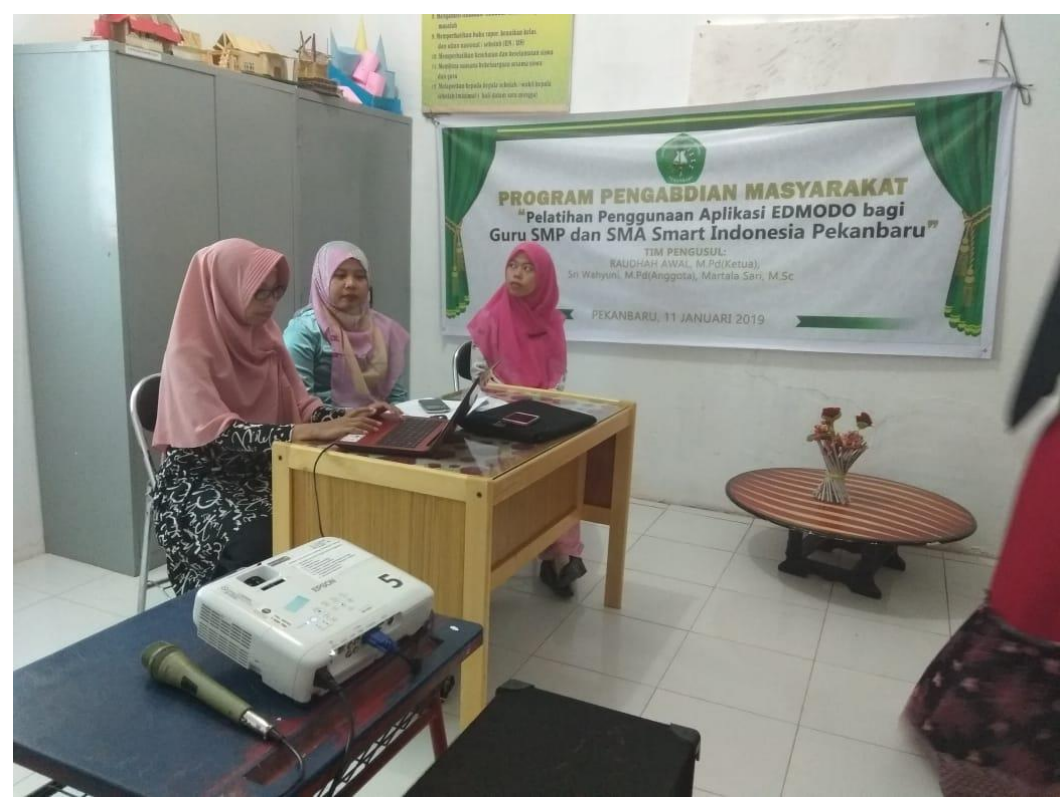

Gambar 3. Praktik Penggunaan Aplikasi Edmodo

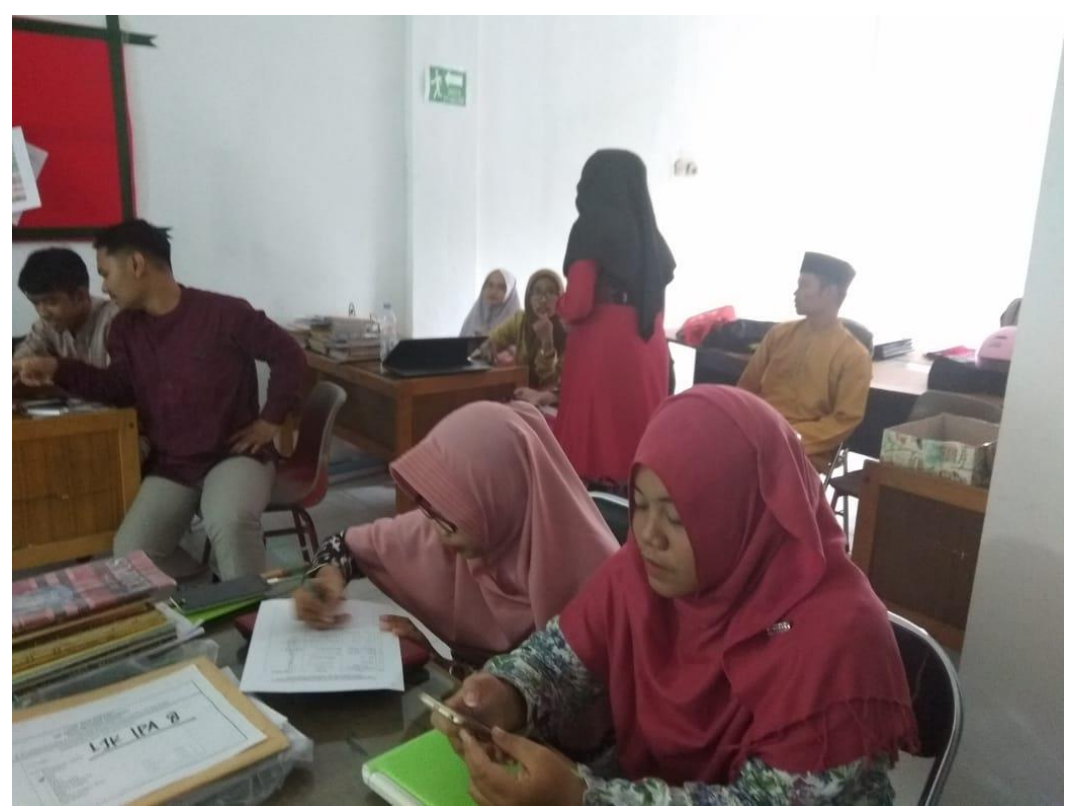

Gambar 4. Pengerjaan Posttest

Setelah kegiatan pengabdian selesai, dilakukan pengolahan data pretest dan posttest. Berikut disajikan hasil prestest dan posttest:

\section{Tabel 3. Hasil Pretest Guru SMP dan SMA Smart Indonesia Pekanbaru}

\begin{tabular}{clcc}
\hline No. & \multicolumn{1}{c}{ Soal/ Pertanyaan } & Tahu & Tidak Tahu \\
\hline 1 & $\begin{array}{l}\text { Pengetahuan tentang aplikasi TIK yang dapat } \\
\text { digunakan untuk pembelajaran }\end{array}$ & $70 \%$ & $30 \%$ \\
\hline 2 & $\begin{array}{l}\text { Pengetahuan tentang pengertian aplikasi } \\
\text { Edmodo }\end{array}$ & $40 \%$ & $60 \%$ \\
\hline
\end{tabular}




\begin{tabular}{clcc}
\hline 3 & $\begin{array}{l}\text { Pengetahuan tentang kegunaan aplikasi } \\
\text { Edmodo }\end{array}$ & $40 \%$ & $60 \%$ \\
\hline 4 & $\begin{array}{l}\text { Pengetahuan tentang cara membuat akun } \\
\text { Edmodo }\end{array}$ & $10 \%$ & $90 \%$ \\
\hline 5 & $\begin{array}{l}\text { Pengetahuan tentang cara membuat grup/ } \\
\text { kelompok pada aplikasi Edmodo }\end{array}$ & $0 \%$ & $100 \%$ \\
\hline 6 & $\begin{array}{l}\text { Pengetahuan tentang cara mengunggah bahan } \\
\text { ajar di library pada aplikasi Edmodo }\end{array}$ & $0 \%$ & $100 \%$ \\
\hline 7 & $\begin{array}{l}\text { Pengetahuan tentang cara membuat catatan/ } \\
\text { note pada aplikasi Edmodo }\end{array}$ & $0 \%$ & $100 \%$ \\
\hline 8 & $\begin{array}{l}\text { Pengetahuan tentang cara membuat } \\
\text { pengumuman/ alert pada aplikasi Edmodo }\end{array}$ & $0 \%$ & $100 \%$ \\
\hline 9 & $\begin{array}{l}\text { Pengetahuan tentang cara membuat penugasan/ } \\
\text { assignment pada aplikasi Edmodo }\end{array}$ & $0 \%$ & $100 \%$ \\
\hline 10 & $\begin{array}{l}\text { Pengetahuan tentang cara membuat calendar } \\
\text { Edmodo }\end{array}$ & $0 \%$ & \\
\hline
\end{tabular}

Berdasarkan hasil pretest di atas diketahui bahwa $30 \%$ peserta tidak mengetahui berbagai aplikasi TIK yang dapat digunakan untuk pembelajaran, $60 \%$ peserta tidak mengetahui pengertian dan kegunaan aplikasi Edmodo, $90 \%$ peserta tidak mengetahui cara membuat akun Edmodo, dan $100 \%$ peserta tidak mengetahui cara menggunakan aplikasi Edmodo. Dari hasil tersebut dapat disimpulkan bahwa peserta tidak memiliki pengetahuan awal mengenai cara menggunakan aplikasi Edmodo dan hanya sebahagian kecil yang mengetahui pengertian, kegunaan, maupun cara membuat akun Edmodo, sehingga kegiatan pengabdian ini memang diperlukan oleh guru-guru di SMP dan SMA Smart Indonesia Pekanbaru.

Tabel 4. Hasil Posttest Guru SMP dan SMA Smart Indonesia Pekanbaru

\begin{tabular}{clcc}
\hline No. & \multicolumn{1}{c}{ Soal/ Pertanyaan } & Tahu & Tidak Tahu \\
\hline 1 & $\begin{array}{l}\text { Pengetahuan tentang aplikasi TIK yang dapat } \\
\text { digunakan untuk pembelajaran }\end{array}$ & $100 \%$ & $0 \%$ \\
\hline 2 & $\begin{array}{l}\text { Pengetahuan tentang pengertian aplikasi } \\
\text { Edmodo }\end{array}$ & $100 \%$ & $0 \%$ \\
\hline 3 & $\begin{array}{l}\text { Pengetahuan tentang kegunaan aplikasi } \\
\text { Edmodo }\end{array}$ & $100 \%$ & $0 \%$ \\
\hline 4 & $\begin{array}{l}\text { Pengetahuan tentang cara membuat akun } \\
\text { Edmodo }\end{array}$ & $100 \%$ & $0 \%$ \\
\hline 5 & $\begin{array}{l}\text { Pengetahuan tentang cara membuat grup/ } \\
\text { kelompok pada aplikasi Edmodo }\end{array}$ & $100 \%$ & $0 \%$ \\
\hline 6 & $\begin{array}{l}\text { Pengetahuan tentang cara mengunggah bahan } \\
\text { ajar di library pada aplikasi Edmodo }\end{array}$ & $100 \%$ & $0 \%$ \\
\hline 7 & $\begin{array}{l}\text { Pengetahuan tentang cara membuat catatan/ } \\
\text { note pada aplikasi Edmodo }\end{array}$ & $100 \%$ & $0 \%$ \\
\hline 8 & $\begin{array}{l}\text { Pengetahuan tentang cara membuat } \\
\text { pengumuman/ alert pada aplikasi Edmodo }\end{array}$ & $100 \%$ & $0 \%$ \\
\hline 9 & $\begin{array}{l}\text { Pengetahuan tentang cara membuat penugasan/ } \\
\text { assignment pada aplikasi Edmodo }\end{array}$ & $100 \%$ & $\begin{array}{l}\text { Pengetahuan tentang cara membuat calendar } \\
\text { Edmodo }\end{array}$ \\
\hline 10 & $100 \%$ & 0 \\
\hline
\end{tabular}

Berdasarkan hasil posttest di atas diketahui bahwa $100 \%$ peserta sudah mengetahui berbagai aplikasi TIK yang dapat digunakan untuk pembelajaran, pengertian dan kegunaan aplikasi Edmodo, cara membuat akun Edmodo, dan cara menggunakan aplikasi Edmodo. Dari hasil 
tersebut dapat disimpulkan bahwa peserta mengikuti kegiatan pelatihan dengan baik, sehingga terdapat peningkatan pengetahuan akhir setelah mengikuti seluruh sesi kegiatan pelatihan.

\section{KESIMPULAN}

Berdasarkan hasil kegiatan pelatihan yang telah dilakukan dapat disimpulkan hal-hal sebagai berikut:

a. Berdasarkan perbandingan hasil pretest dan posttest diketahuin kegiatan pelatihan dapat meningkatkan wawasan peserta terkait berbagai aplikasi TIK yang dapat digunakan untuk pembelajaran, pengertian dan kegunaan aplikasi Edmodo, cara membuat akun Edmodo, dan cara menggunakan aplikasi Edmodo.

b. Berdasarkan hasil praktik peserta pelatihan terlihat bahwa peserta sudah memahami cara membuat akun dan menggunakan aplikasi Edmodo.

\section{SARAN}

Hasil pelatihan ini menunjukkan bahwa pelatihan yang telah dilakukan memberikan dampak positif terhadap peserta. Sehubungan dengan itu hendaknya kegiatan-kegiatan yang mengarah pada penguatan wawasan mengenai aplikasi maupun program yang mendukung pembelajaran agar lebih sering dilakukan.

\section{DAFTAR PUSTAKA}

[1] Budiana, H. R. et al. 2015. Pemanfaatan Teknologi Informasi dan Komunikasi dalam Pembelajaran bagi Para Guru SMPN 2 Kawali Desa Citeureup Kabupaten Ciamis. Dharmakarya: Jurnal Aplikasi Ipteks Untuk Masyarakat. Vol. 4, No. 1, Mei 2015: 59 - 62.

[2] Darimi, I. 2017. Teknologi Informasi dan Komunikasi Sebagai Media Pembelajaran Pendidikan Agama Islam Efektif. Cyberspace: Jurnal Pendidikan Teknologi Informasi, Volume 1, Nomor 2, Oktober 2017, 111-121.

[3] Fahyuni, E.F. 2017. Teknologi, Informasi dan Komunikasi (Prinsip dan Aplikasi dalam Studi Pemikiran Islam). Umsida Press: Sidoarjo.

[4] Okmayura, F. et al. 2018. Peningkatan Profesionalisme Guru Melalui Pelatihan Pembelajaran Berbasis Learning Management System (LMS) dengan Aplikasi Edmodo bagi Para Guru Bidang Kejuruan di SMK Masmur Pekanbaru. Laporan Kegiatan Pengabdian Kepada Masyarakat. Program Studi Pendidikan Vokasional Teknik Elektronika: Universitas Muhammadiyah Riau.

[5] Siahaan, S. 2010. Pemanfaatan Teknologi Informasi dan Komunikasi dalam Pembelajaran. Jakarta: Pustekkomdiknas. 